\section{Zinc Availability in Hydroponic Culture Influences Glucosinolate Concentrations in Brassica rapa}

\author{
Timothy W. Coolong ${ }^{1}$ and William M. Randle ${ }^{2}$ \\ Department of Horticulture, University of Georgia, Athens, GA 30602
}

\author{
Heather D. Toler ${ }^{3}$ and Carl E. Sams ${ }^{4}$ \\ Department of Plant Sciences, University of Tennessee, Knoxville, TN 37996
}

Additional index words. progoitrin, glucoraphanin, sinigrin, cluconapin, glucosinalbin, glucobrassicin, 4-methoxyglucobrassicin, gluconasturtiin, neoglucobrassicin

\begin{abstract}
Rapid cycling Brassica rapa $L$. were grown for 7 days in the presence of 11 levels of zinc (Zn) in hydroponic solution culture and evaluated for changes in $\mathrm{Zn}$ and glucosinolate (GS) content. Zinc levels were $0.05,1,5,10,25,50,75,100,125,150$, and $200 \mathrm{mg} \cdot \mathrm{L}^{-1} \mathrm{Zn}$. Plants grown in solutions with $\geq 50 \mathrm{mg} \cdot \mathrm{L}^{-1} \mathbf{Z n}$ displayed severe $\mathbf{Z n}$ toxicity symptoms, grew little, or died and were not subsequently evaluated for GS content. Shoot Zn concentrations increased linearly with increasing $\mathbf{Z n}$ treatment levels. Gluconapin, which accounted for nearly $90 \%$ of the aliphatic GSs present, was the only aliphatic GS influenced by $\mathrm{Zn}$, and decreased linearly with increasing $\mathrm{Zn}$ levels. Accumulation of glucobrassicin and 4-methoxyglucosbrassicin, both indole GSs, responded with a linear increase and quadratically, respectively, to $\mathrm{Zn}$ fertility. An aromatic GS, gluconasturtiin, was also influenced by $\mathrm{Zn}$ levels in solution, and had a quadratic response to increasing $\mathrm{Zn}$. This suggested that $\mathrm{Zn}$ fertility can influence changes in GS that may affect flavor (bitterness, etc.) or medicinal attributes associated with the GS and their breakdown products, as well as elevate the nutritional status of $\mathrm{Zn}$ in the leaves of Brassica.
\end{abstract}

Glucosinolates (GSs) are a broad class of sulfur-based secondary metabolites containing $\beta$-thioglucose-moieties found in 16 families of dicotyledonous plants (Mithen, 2001). At least 120 different GSs have been identified, many of these isolated from Brassicacea and Capparacea, which have species with economic importance (Fahey et al., 2001). When plant tissue is disrupted, myrosinases hydrolyze intact GSs, causing the formation of several biologically active compounds, including nitriles, thiocyanates, and isothiocyanates (Wittstock and Halkier, 2002).

Because many of the GS breakdown products have high biological activity, plant GS content has been of interest to researchers for some time. Early work conducted on Brassica was focused on the harmful effects of some GSs, which produced goitrogenic effects in livestock (Chesney et al., 1928; Fenwick et al., 1983; Stoewsand, 1995). Recently, however, GSs and their hydrolyzed products have been investigated for anticarcinogenic properties (Das et al., 2000; Fenwick et al., 1983; Kristal, 2002; McDanell et al., 1988; Mithen, 2001; Verhoeven et al., 1997), as well as the ability to act as soil fumigants and the suppression of pathogenic Pythium sp. and several types of nematode (Charron and Sams, 1999; Chitwood, 2002; Lazzeri and Manici, 2001;

Received for publication 5 May 2003. Accepted for publication 30 Sept. 2003.

${ }^{1}$ Graduate Assistant.

${ }^{2}$ Professor; to whom reprint requests should be addressed.E-mail: wrandle@uga.edu

${ }^{3}$ Graduate Assistant.

${ }^{4}$ Professor.
Mizutani, 1999; Morra and Kirkegaard, 2002). Glucosinolates also influence the flavor of these plants. Researchers are now investigating ways to alter levels of GSs in some crops. Although genetics ultimately limits GS content in plants, the growing environment can dramatically influence GS levels as well. Water stress and high growing temperatures lead to increased GS content of several Brassica species (Mailer and Cornish, 1987; Mailer and Pratley, 1990; Rosa and Rodrigues, 1998). Sulfur and nitrogen fertility regimes have also influenced GS levels in plants, with $\mathrm{S}$ fertility generally having greater impact than N (Booth et al., 1991; Kim et al., 2002; Mailer, 1989; Milford and Evans, 1991; Zhao et al., 1994).

Zinc, an essential plant element and an important mineral for maintaining human health (Branca and Ferrari, 2002), was recently reported to influence GSs levels of Thlaspi caerulescens, which can hyperaccumulate $\mathrm{Zn}$ (Tolra et al., 2001). With increasing Zn levels supplied through hydroponic nutrient solutions, plant GS content generally decreased, especially sinalbin (p-hydroxybenzylglucosinolate). Earlier, Jiracek et al. (1974) reported that increasing $\mathrm{Zn}$ fertility levels increased glucosbrassicin and neoglucobrassicin in etiolated seedlings of $B$. napus. The scope of that investigation was limited, however, as only the indole GSs were measured. Because $\mathrm{Zn}$ fertility influenced total $\mathrm{S}$ accumulation in B. rapa (Coolong and Randle, 2003), we felt it important to determine the impact of increasing $\mathrm{Zn}$ on GS content as well. Our purpose, therefore, was to evaluate the effects of a wide range of Zn fertility levels on detectable GSs in hydroponically grown $B$. rapa.
Plant culture. On 10 Oct. 2001, seeds of a rapid-cycling B. rapa (Carolina Biological Supply, Burlington, N.C.) were sown into $16-\mathrm{cm}^{3}$ rockwool cubes (Grodan, Hedehusene, Denmark). Seeds were germinated at $20{ }^{\circ} \mathrm{C}$ under a 24 -h photoperiod in growth chambers that were tested for uniformity (Conviron, Pembina, N.Dak.). Average light intensity was $352 \mu \mathrm{mol} \cdot \mathrm{m}^{-2} \cdot \mathrm{s}^{-1}$, measured at the base of the plant using a Basic Quantum Meter (Spectrum Tech., Plainfield, Ill.). Three-day-old seedlings were transferred to 5.4-L plastic containers (Rubbermaid Inc., Wooster, Ohio). Six plants were placed in holes in each container lid spaced $\approx 6 \mathrm{~cm}$ apart. The tubs were filled with $4 \mathrm{~L}$ of a modified Hoagland's \#2 solution (Hoagland and Arnon, 1950). The solutions consisted of: $0.47 \mathrm{~g} \cdot \mathrm{L}^{-1}$ $\mathrm{Ca}\left(\mathrm{NO}_{3}\right)_{2} \cdot 4 \mathrm{H}_{2} \mathrm{O}, 0.30 \mathrm{~g} \cdot \mathrm{L}^{-1} \mathrm{KNO}_{3}, 0.06 \mathrm{~g} \cdot \mathrm{L}^{-1}$ $\mathrm{NH}_{4} \mathrm{H}_{2} \mathrm{PO}_{4}, 0.25 \mathrm{~g} \cdot \mathrm{L}^{-1} \mathrm{MgSO}_{4} \cdot 7 \mathrm{H}_{2} \mathrm{O}, 0.1 \mathrm{~g} \cdot \mathrm{L}^{-1}$ Iron Chelate (Sequestrene 330), $2.86 \mathrm{mg} \cdot \mathrm{L}^{-1}$ $\mathrm{H}_{3} \mathrm{BO}_{3}, 1.81 \mathrm{mg} \cdot \mathrm{L}^{-1} \mathrm{MnCl}_{2} \cdot 4 \mathrm{H}_{2} \mathrm{O}, 0.22 \mathrm{mg} \cdot \mathrm{L}^{-1}$ $\mathrm{ZnSO}_{4} \cdot 7 \mathrm{H}_{2} \mathrm{O}, 0.08 \mathrm{mg} \cdot \mathrm{L}^{-1} \mathrm{CuSO}_{4} \cdot 5 \mathrm{H}_{2} \mathrm{O}$, and $0.02 \mathrm{mg} \cdot \mathrm{L}^{-1} \mathrm{Na}_{2} \mathrm{MoO}_{4} \cdot 2 \mathrm{H}_{2} \mathrm{O}$. Solutions were aerated via a $2.5-\mathrm{cm}$ aquarium airstone. Plants were grown at $20^{\circ} \mathrm{C}$ and a constant 24 -h photoperiod for $6 \mathrm{~d}$. Eleven $\mathrm{Zn}$ treatments were then imposed, with each treatment replicated three times with individual growth chambers acting as replications, in a completely randomized design. Zinc was supplied using $\mathrm{ZnSO}_{4} \cdot 7 \mathrm{H}_{2} \mathrm{O}$. The treatment levels were: $0.05,1,5,10,25$, $50,75,100,125,150$, and $200 \mathrm{mg} \cdot \mathrm{L}^{-1} \mathrm{Zn}$. The $0.05 \mathrm{mg} \cdot \mathrm{L}^{-1} \mathrm{Zn}$ represented normal $\mathrm{Zn}$ levels in the standard nutrient solution. Sulfur levels were balanced with the addition of $\mathrm{MgSO}_{4} \cdot 7 \mathrm{H}_{2} \mathrm{O}$ so that all treatments had 129 $\mathrm{mg} \cdot \mathrm{L}^{-1} \mathrm{~S}$. Magnesium levels were equalized by the addition of $\mathrm{MgCl}_{2} \cdot 6 \mathrm{H}_{2} \mathrm{O}$ to the solutions. Each solution then contained $94 \mathrm{mg} \cdot \mathrm{L}^{-1}$ of $\mathrm{Mg}^{2+}$. Chloride levels, therefore, varied between solutions. The $\mathrm{pH}$ of the solutions ranged from 5.5 to 6.0 at the initiation of the experiment and did not change appreciably. Electrical conductivity (EC) (model 09-3262; Fisher Scientific, Pittsburgh) measurements of the solutions were made at the beginning and end of the experiment. The average EC of solutions at the initiation of the experiment was $1148 \mu \mathrm{S} \cdot \mathrm{cm}^{-2}$. When $\mathrm{Zn}$ was added, the EC increased to $1487 \mu \mathrm{S} \cdot \mathrm{cm}^{-2}$ for the 0.05 $\mathrm{mg} \cdot \mathrm{L}^{-1} \mathrm{Zn}$ treatment and to $2200 \mu \mathrm{S} \cdot \mathrm{cm}^{-2}$ for the $200 \mathrm{mg} \cdot \mathrm{L}^{-1} \mathrm{Zn}$ treatment. At harvest, EC ranged from 1045 to $2040 \mu \mathrm{S} \cdot \mathrm{cm}^{-2}$. Solution volumes were maintained daily with deionized water. After $7 \mathrm{~d}$ exposure to the $\mathrm{Zn}$ treatments, plants were harvested and weighed. The shoots were dried at $65{ }^{\circ} \mathrm{C}$ for $72 \mathrm{~h}$ in a forced-air oven (Linberg Blue, Asheville, N.C.). Dried tissue was weighed and then ground through a $0.5-\mathrm{mm}$ screen attached to a Cyclotec Mill (model 1093; Tector, Hoganas, Sweden) and stored at $25^{\circ} \mathrm{C}$ in $60-\mathrm{mL}$ plastic vials.

\section{Zinc determination}

Zinc was extracted from $0.1 \mathrm{~g}$ tissue using a nitric acid digestion procedure. A national institute of standards and technol- 
ogy (NIST) standard 1573 (tomato leaves, NIST, Washington, D.C.) was also digested to establish $\mathrm{Zn}$ recovery and quantification. Following digestion at $125^{\circ} \mathrm{C}$ in $5 \mathrm{~mL}$ of nitric acid, $5 \mathrm{~mL}$ of $30 \% \mathrm{H}_{2} \mathrm{O}_{2}$ were added in $1-\mathrm{mL}$ aliquots. The solutions were allowed to cool and brought to a final volume of $50 \mathrm{~mL}$ using HPLC grade water. $\mathrm{Zn}$ concentrations were determined using a Perkin-Elmer 5000 flame atomic absorption spectrometer and a $\mathrm{Zn}-\mathrm{Mn}-\mathrm{Cu}$ hollow cathode lamp (Intersitron Model 303-6105, Perkin-Elmer, Boston). The wavelength was set at $213.9 \mathrm{~nm}$ and slit width was $0.7 \mathrm{~nm}$. Detection limits were $0.16 \mathrm{mg} \cdot \mathrm{kg}^{-1}$. Triplicate analysis of the NIST standard showed recovery between $93 \%$ and $106 \%$.

\section{Glucosinolate analysis}

Extraction of glucosinolates. Glucosinolate analysis was performed using high performance liquid chromatography (HPLC) according to Raney and McGregor (1990), with several modifications. Two milliliters of methanol were added to $200 \mathrm{mg}$ of dried tissue, then $1 \mathrm{~mL}$ of $1 \mathrm{mmol}$ glucotropaeolin internal standard solution (Bioraf Denmark Foundation, Aakirkeby, Denmark) and 0.1 $\mathrm{mL}$ of barium lead-acetate were added in sequential order. The mixture was shaken for $1 \mathrm{~h}$ on a Vortex-Genie 2 shaker (model \#G560; Scientific Industries, Bohemia, N.Y.) at $60 \mathrm{rpm}$. This mixture was centrifuged at 2000 $g_{\mathrm{n}}$ for $10 \mathrm{~min}$ in a Centra-MP4R centrifuge [International Equipment Co. (IEC), Needham Heights, Mass.] using an IEC 224 swing bucket rotor (IEC). The supernatant was transferred to a diethylaminoethyl(DEAE) Sephadex A25 (Sigma-Aldrich, St. Louis) column, where it was subjected to ion exchange chromatography by washing with $1.8 \mathrm{~mL}$ of 2 methanol:1 water, $1.8 \mathrm{~mL}$ water, $0.9 \mathrm{~mL} 0.02 \mathrm{~m}$ pyridine-acetate, and $0.05 \mathrm{~mL}$ purified sulfatase in that order. After $24 \mathrm{~h}$, samples were eluted from the column with $0.9 \mathrm{~mL}$ double deionized water for

Table 1. Mean ( \pm SE) dry weight (DW) and zinc (Zn) uptake for Brassica rapa grown with different levels of $\mathrm{Zn}$ in solution culture.

\begin{tabular}{lcc}
\hline $\begin{array}{l}\text { Solution Zn } \\
\left(\mathrm{mg} \cdot \mathrm{L}^{-1}\right)\end{array}$ & $\begin{array}{c}\text { Shoot DW } \\
(\mathrm{g} / \mathrm{plant})\end{array}$ & $\begin{array}{c}\text { Shoot Zn } \\
\left(\mathrm{mg} \cdot \mathrm{kg}^{-1} \mathrm{DW}\right)\end{array}$ \\
\hline 0.05 & $2.1 \pm 0.1$ & $65 \pm 6$ \\
1 & $2.6 \pm 0.2$ & $304 \pm 1$ \\
5 & $1.2 \pm 0.1$ & $1764 \pm 161$ \\
10 & $1.0 \pm 0.2$ & $2433 \pm 335$ \\
25 & $0.9 \pm 0.1$ & $4238 \pm 101$ \\
Regression $^{\mathrm{z}}$ & $\mathrm{Q}$ & $\mathrm{L}$ \\
\hline
\end{tabular}

${ }^{\mathrm{z}}$ Significant at $P<0.01$; linear $(\mathrm{L})$, quadratic $(\mathrm{Q})$ regression.
HPLC analysis. DEAE columns were regenerated for reuse by rinsing with $1 \mathrm{~mL} 1 \mathrm{M}$ sodium acetate, $1 \mathrm{~mL} 0.5 \mathrm{~m}$ sodium hydroxide, $1 \mathrm{~mL}$ 0.5 hydrochloric acid, and $3.6 \mathrm{~mL}$ nanopure water in sequential order.

Purification of sulfatase. Sulfatase was purchased, unpurified, from Sigma-Aldrich. Seventy milligrams of unpurified sulfatase was massed into a centrifuge tube. Three milliliters of nanopure water was added in order to dissolve the sulfatase, followed by $3 \mathrm{~mL}$ of absolute ethanol. The mixture was centrifuged for $20 \mathrm{~min}$ at $2000 \mathrm{~g}_{\mathrm{n}}$ on the Centra-MP4R Centrifuge using an IEC 224 swing bucket rotor (IEC). The supernatant was decanted into a second culture tube, the precipitate discarded, and $9 \mathrm{~mL}$ of absolute ethanol added to the supernatant. The solution was centrifuged for $15 \mathrm{~min}$ at $2000 \mathrm{~g}$ on the Centra-MP4R Centrifuge using an IEC 224 swing bucket rotor (IEC). The supernatant liquid was discarded and the remaining precipitate dissolved in 2.5 $\mathrm{mL}$ of water. The purified sulfatase was then frozen until use.

HPLC analysis. The samples were separated on a Hewlett-Packard separations module coupled to a HP1050 Series Variable Wavelength Detector (Hewlett Packard, Palo Alto, Calif.), set at $227 \mathrm{~nm}$. Fifty microliters of sample were injected into a $250 \times 4.60 \mathrm{~mm}$ $5 \mu \mathrm{C} 18$ column (Phenomenex ODS Hypersil; Phenomenex, Torrence, Calif.). Mobile phase solvents were: 1 ) nanopure water and 2) acetonitrile (HPLC grade; Fisher Scientific, Atlanta). A gradient run with a constant flow-rate of 1 $\mathrm{mL} \cdot \mathrm{min}^{-1}$ was programmed as follows: $100 \% \pm$ $1 \mathrm{~min}, 75 \% \pm 15 \mathrm{~min}, 75 \% \pm 20 \mathrm{~min}, 100 \% \pm$ $25 \mathrm{~min}$. Identification of desulfonated GS peaks was determined by running desulfonated GS standards for 2(R)-2-hydrooxy-3-butenyl GS (progoitrin), 4-methylsulfinyl-3-butenyl GS (glucoraphanin), 2-propenyl GS (sinigrin), 4-hydroxybenzyl GS (glucosinalbin), 3-butenyl GS (gluconapin), indolyl-3-methyl GS (glucobrassicin), 4-methoxyindolyl-3-methyl GS (4-methoxyglucobrassicin), 2-phenylethyl GS (gluconasturtiin), and 1-methoxyinolyl3-methyl GS (neoglucobrassicin) using the above method and comparing retention times of standards to samples. Integration of peaks was performed on Chemstation Software Module, version 6.03 (Hewlett Packard).

Statistical analysis. All data was subjected to analysis of variance and linear or polynomial regression using SAS statistics software. (Version 8.2, SAS Institute, Cary, N.C.). Orthagonal contrasts among treatments were also performed. Data more than two standard deviations from the mean of the particular treatment were treated as outlying data and removed from the analysis. As a result, one replication from three different treatments was removed from the analysis.

\section{Results and Discussion}

\section{Shoot dry weight, zinc uptake, and plant condition}

Shoot dry weight (DW) was influenced $(P<$ 0.01 ) by $\mathrm{Zn}$ treatments and ranged from 0.9 to $2.6 \mathrm{~g} /$ plant (Table 1). The trend was quadratic $\left.\left.[\mathrm{y}=2.42-0.22(\mathrm{Zn})+0.0062) \mathrm{Zn}^{2}\right], r^{2}=0.78\right)$, increasing from 0.05 to $1.0 \mathrm{mg} \cdot \mathrm{L}^{-1} \mathrm{Zn}$ and then decreasing as the $\mathrm{Zn}$ solution concentrations increased to $25 \mathrm{mg} \cdot \mathrm{L}^{-1} \mathrm{Zn}$. Plants grown with 5 and $10 \mathrm{mg} \cdot \mathrm{L}^{-1} \mathrm{Zn}$ exhibited toxicity symptoms (marginal chlorosis, decreased dry matter accumulation, and some root death). Above $25 \mathrm{mg} \cdot \mathrm{L}^{-1} \mathrm{Zn}$, plants grew little and exhibited strong symptoms of $\mathrm{Zn}$ toxicity. Nearly all plants grown in solutions $\geq 50 \mathrm{mg} \cdot \mathrm{L}^{-1} \mathrm{Zn}$ were severely stunted, dead, or were dying following $7 \mathrm{~d}$ of exposure. As such, plants from $\geq 50$ $\mathrm{mg} \cdot \mathrm{L}^{-1} \mathrm{Zn}$ treatments were not analyzed for GS content due to insufficient tissue.

Shoot $\mathrm{Zn}$ concentrations were affected by solution $\mathrm{Zn}$ levels $(P<0.01)$ and ranged from 65 to $4238 \mathrm{mg} \cdot \mathrm{kg}^{-1} \mathrm{DW}$. The response was linear to increasing $\mathrm{Zn}$ treatment [y $=429.78$ $\left.+167.01(\mathrm{Zn}), R^{2}=0.92\right]$ (Table 1). Despite the observation that the plants grew very little, especially following exposure to the higher $\mathrm{Zn}$ concentrations, the plants continued to accumulate $\mathrm{Zn}$ in shoots. Subsequent preliminary studies indicate that $\mathrm{Zn}$ accumulates in the shoots of Allium cepa seedlings rather quickly, perhaps accumulating in large amounts prior to the exhibition of toxicity symptoms and the cessation of growth (Coolong and Randle, unpublished data).

\section{Shoot glucosinolate content}

Aliphatic glucosinolates. Of the five aliphatic GSs measured, gluconapin was found in highest concentration and was the only one that responded to increasing $\mathrm{Zn}$ levels $(P<$ $0.02)$. Progoitrin, glucoraphin, sinigrin, and glucosinalbin were not significantly influenced by Zn fertility (Table 2). Gluconapin concentrations decreased linearly to increasing $\mathrm{Zn}[\mathrm{y}=$ $\left.9.98-0.23(\mathrm{Zn}), R^{2}=0.66\right]$. Correspondingly, small decreases in root gluconapin concentrations were reported when the Zn hyperaccumulator T. caerulescens was grown at high $\mathrm{Zn}$

Table 2. Mean $( \pm \mathrm{SE})$ shoot glucosinolate concentrations for Brassica rapa grown at different levels of zinc (Zn) in solution culture (nd indicates not detectable).

\begin{tabular}{|c|c|c|c|c|c|c|c|c|c|}
\hline $\begin{array}{l}\text { Solution } \mathrm{Zn} \\
\left(\mathrm{mg} \cdot \mathrm{L}^{-1}\right)\end{array}$ & Progoitrin & Glucoraphanin & Sinigrin & Gluconapin & Glucosinalbin & Glucobrassicin & $\begin{array}{l}\text { 4-Methoxy- } \\
\text { glucobrassicin }\end{array}$ & $\begin{array}{c}\text { Gluco } \\
\text {-nasturtiin }\end{array}$ & $\begin{array}{c}\text { Neogluco- } \\
\text { brassicin }\end{array}$ \\
\hline & & & & & $---\left(\mu \mathrm{mol} \cdot \mathrm{g}^{-1}\right.$ & V) $-\cdots$ & & & - - \\
\hline 0.05 & $0.04 \pm 0.01$ & $0.48 \pm 0.04$ & $0.07 \pm 0.01$ & $10.42 \pm 0.44$ & $0.15 \pm 0.01$ & $1.04 \pm 0.12$ & $0.16 \pm 0.02$ & $0.76 \pm 0.05$ & $0.34 \pm 0.09$ \\
\hline 1 & nd & $0.47 \pm 0.14$ & $0.06 \pm 0.03$ & $10.48 \pm 1.43$ & $0.17 \pm 0.04$ & $0.89 \pm 0.12$ & $0.14 \pm 0.003$ & $0.64 \pm 0.11$ & $0.28 \pm 0.06$ \\
\hline 5 & $0.07 \pm 0.01$ & $0.69 \pm 0.10$ & $0.06 \pm 0.01$ & $8.74 \pm 0.16$ & $0.26 \pm 0.04$ & $1.81 \pm 0.04$ & $0.32 \pm 0.06$ & $0.93 \pm 0.03$ & $0.52 \pm 0.06$ \\
\hline 10 & $0.05 \pm 0.01$ & $0.78 \pm 0.11$ & $0.09 \pm 0.03$ & $6.58 \pm 1.58$ & $0.18 \pm 0.03$ & $2.17 \pm 0.38$ & $0.39 \pm 0.08$ & $0.98 \pm 0.17$ & $0.44 \pm 0.06$ \\
\hline 25 & $0.05 \pm 0.003$ & $0.91 \pm 0.32$ & $0.09 \pm 0.02$ & $4.79 \pm 0.74$ & $0.16 \pm 0.03$ & $3.09 \pm 0.63$ & $0.35 \pm 0.02$ & $0.51 \pm 0.03$ & $0.29 \pm 0.03$ \\
\hline Regression $^{z}$ & NS & NS & NS & $\mathrm{L}$ & NS & $\mathrm{L}$ & Q & Q & NS \\
\hline
\end{tabular}

Ns Nonsignificant at $P<0.05$; linear (L), quadratic (Q). 
concentrations (Tolra et al., 2001). Gluconapin was also reported to constitute a large portion of the aliphatic GS content in $B$. rapa (Kim et al., 2002). In our study, gluconapin was responsible for between $81 \%$ to $94 \%$ of the total aliphatic GSs measured, and ranged between 10.5 and $4.8 \mu \mathrm{mol} \cdot \mathrm{g}^{-1} \mathrm{DW}$. Our data suggests that higher $\mathrm{Zn}$ availability may be a way to suppress gluconapin accumulation in the plant. Gluconapin content was highly correlated with bitterness and using $\mathrm{Zn}$ fertility to decrease gluconapin concentrations may be useful for improving tissue palatability (Fenwick et al., 1990; Mithen, 2001). However, decreased gluconapin content was highly correlated to decreased shoot DW $(r=0.84)$ and suggests that gluconapin suppression was linked to $\mathrm{Zn}$ toxicity. Further work with Zn on edible Brassica sp. may prove useful as a way of increasing Zn content in the diet and reducing potentially unpalatable glucosinolates. Edible Brassica are low in oxalates, which bind elements like $\mathrm{Zn}$, and could be an excellent vehicle for delivering micronutrients to our diet.

Indole and aromatic glucosinolates. Of the indole GSs measured, glucobrassicin $(P$ $<0.006)$ and 4-methoxyglucobrassicin $(P<$ 0.008 ,) were affected by $\mathrm{Zn}$ in solution, whereas neoglucobrassicin was not. Glucobrassicin responded linearly, increasing as $\mathrm{Zn}$ levels increased $\left[\mathrm{y}=1.1+0.085(\mathrm{Zn}), R^{2}=0.68\right]$ (Table 2). Shoot glucobrassicin concentrations ranged from 0.89 to $3.09 \mu \mathrm{mol} \cdot \mathrm{g}^{-1} \mathrm{DW}$, and were within the range to those previously reported for $B$. rapa. (Kim et al., 2002). Similarly, Jiracek et al. (1974) reported a slight increase in glucobrassicin content in B. napus when etiolated seedlings were exposed to increasing levels of $\mathrm{Zn}$. 4-Methoxyglucobrassicin responded quadratically to increasing $\mathrm{Zn}[\mathrm{y}=0.13+0.039(\mathrm{Zn})$ $\left.-0.0012\left(\mathrm{Zn}^{2}\right), r^{2}=0.69\right]$. Shoot 4-methoxyglucobrassicin concentrations ranged from 0.14 to $0.39 \mu \mathrm{mol} \cdot \mathrm{g}^{-1} \mathrm{DW}$ (Table 2). Therefore, unlike the responsive aliphatic GS that decreased at higher $\mathrm{Zn}$ fertility levels, the response of the indoles generally increased.

Gluconasturtiin, the only aromatic GS measured, was influenced by $\mathrm{Zn}(P<0.03)$ with a quadratic response to increasing $\mathrm{Zn}$ in the solutions $\left(\mathrm{y}=0.68+0.056(\mathrm{Zn})-0.0025\left(\mathrm{Zn}^{2}\right)\right.$, $\left.r^{2}=0.58\right)$. Gluconasturtiin shoot concentrations ranged from 0.51 to $0.93 \mu \mathrm{mol} \cdot \mathrm{g}^{-1} \mathrm{DW}$ (Table 2 ), which were lower than values obtained by Kim et al., (2002) for B. rapa. A breakdown product of gluconasturtiin, phenylethyl isothiocyanate, has been reported to have watercress-like flavor attributes with very low odor threshold when compared to the breakdown products of other GSs (Fenwick et al., 1983).

\section{Conclusions}

Zinc fertility changes were associated with changes in gluconapin, glucobrassicin, 4-methoxyglucobrassicin, and gluconasturtiin levels with the plant. This confirms earlier reports that
$\mathrm{Zn}$ levels can influence concentrations of the indole GSs, but also indicates that the aliphatic and aromatic GSs in Brassica are influenced by $\mathrm{Zn}$ fertility. Although the full range of available Zn used in this experiment would be difficult to duplicate in a terrestrial grown crop, orthogonal contrasts among treatments indicate that statistically significant changes in GS content occurred among relatively small changes in $\mathrm{Zn}$ levels (1-5 $\left.\mathrm{mg} \cdot \mathrm{L}^{-1} \mathrm{Zn}\right)$. Our data also supports the findings that the changes in GS resulting from $\mathrm{Zn}$ fertility differences may affect the flavor (bitterness, etc.) or medicinal attributes associated with the GS and their breakdown products. Furthermore, the combination of enhanced $\mathrm{Zn}$ accumulation along with an overall depression in GS accumulation following an elevated $\mathrm{Zn}$ fertility program may be worthy of future study within Brassica as a way of addressing micronutrient malnutrition through improved food palatability.

\section{Literature Cited}

Booth, E.J., K.C. Walker, and D.W. Griffiths. 1991. A time-course study of the effect of sulphur on glucosinolates in oilseed rape (Brassica napus) from the vegetative stage to maturity. J. Sci. Food Agr. 56:479-493.

Branca, F. and M. Ferrari. 2002. Impact of micronutrient deficiencies on growth: The stunting syndrome. Ann. Nutri. and Metabolism 46: 8-17.

Charron, C.S. and C.E. Sams. 1999. Inhibition of Pythium ultimum and Rhizoctonia solani by shredded leaves of Brassica species. J. Amer. Soc. Hort. Sci. 125:462-467.

Chesney, A.M., T.A. Clawson, and B. Webster. 1928. Endemic goiter in rabbits. I. Incidence and characteristics. Bul. Johns Hopkins Hosp. 43:261-277.

Chitwood, D.J. 2002. Phytochemical based strategies for nematode control. Annu. Rev. Phytopath. 40:221-249.

Coolong, T.W. and W.M. Randle. 2003.Zinc concentration in hydroponic solution culture influences zinc and sulfur accumulation in Brassica rapa L. J. Plant. Nutr. 26:949-959.

Das, A., K. Tyagi, and H. Kaur. 2000. Cancer modulation by glucosinolates: A review. Curr. Sci. 79:1665-1671.

Fahey J.W., A.T. Zalcmann, and P. Talalay. 2001. The chemical diversity and distribution of glucosinolates and isothiocyanates among plants. Phytochemistry 56:5-51.

Fenwick, G.R., C.L. Curl, N.M. Griffiths, R.K. Heaney, and K.R. Price. 1990. Bitter principles in food plants, p. 205-250. In: R.L. Rouseff (ed.). Bitterness in foods and beverages; developments in food science 25. Elsevier, Amsterdam.

Fenwick, G.R., R.K. Heaney, and W.J. Mullin. 1983. Glucosinolates and their breakdown products in food and food plants. CRC Crit. Rev. Food Sci. Nutr. 18:123-201.

Hoagland, D.R. and D.I. Arnon. 1950. The water culture method for growing plants without soil. Calif. Agr. Expt. Sta. Circ. 347:4-32.

Jiracek, V., M. Kutacek, S. Salkade, and J. Kostir. 1974. Effect of zinc on the biosynthesis of indole glucosinolates glucobrassicin and neoglucobrassicin in etiolated seedlings of rape [Brassica na- pus var. arvensis (Lam.) Thell]. Biologia Plant. (Praha) 16:454-461.

Kim, S.J., R. Matsuo, M. Watanabe, and Y. Watanabe. 2002. Effect of nitrogen and sulphur application on the glucosinolate content of vegetable turnip rape (Brassica rapa L.). Soil Sci. Plant Nutr. 48:43-49.

Kristal,A.R. 2002. Brassica vegetables and prostate cancer risk: A review of the epidemiologic evidence. Pharmaceutical Biol. 40:55-58.

Lazzeri,L. and M. Mancini. 2001. Allelopathic effect of glucosinolate-containing plant green manure on Pythium sp. and total fungal population in soil. HortScience 36:1283-1289.

Mailer, R.J. 1989. Effects of applied sulphur on glucosinolate and oil concentrations in the seeds of rape (Brassica napus L.) and turnip rape [Brassica rapa L. var. silvestris (Lam.) Briggs]. Austral. J. Agr. Res. 40:617-624.

Mailer, R.J. and P.S. Cornish. 1987. Effects of water stress on glucosinolate and oil concentrations in the seeds of rape (Brassica napus L. and turnip rape [Brassica rapa L. var. silverstris (Lam.) Briggs]. Austral. J. Expt. Agr. 27:707-711.

Mailer, R.J. and J.E. Pratley. 1990. Field studies on moisture availability effects on glucosinolate and oil concentration in the seed of rape (Brassica napus L.) and turnip rape [Brassica rapa L. var. silvestris (Lam.) Briggs]. Can. J. Soil Sci. 70:399-407.

McDanell, R., A.E.M. McLean, A.B. Hanley, R.K. Heaney, and G.R. Fenwick. 1988. Chemical and biological properties of indole glucosinolates (glucobrassicins): A review. Food and Chem. Toxicol. 26:59-70.

Milford, G.F.J. and E.J. Evans. 1991. Factors causing variation in glucosinolates in oilseed rape. Outlook on Agr. 20:31-37.

Mithen, R.F. 2001. Glucosinolates and their degradation products. Adv. Bot. Res. 35:213-262.

Mizutani, J. 1999. Selected allelochemicals. Crit. Rev. Plant Sci. 18:653-671.

Morra, M.J., and J.A. Kirkegaard. 2002. Isothiocyanate release from soil-incorporated Brassica tissues. Soil Biol. Biochem. 34:1683-1690.

Raney, J.P. and D.I. McGregor. 1990. Determination of glucosinolate content by gas liquid chromatography of trimethylsilyl derivatives of desulfonated glucosinolates. Proc. Oil Crops Network, Shanghai, China, 21-23 Apr. 1990.

Rosa, E.A. and P.M.F. Rodrigues. 1998. The effect of light and temperature on glucosinolate concentrations in the leaves and roots of cabbage seedlings. J. Sci. Food Agr. 78:208-212.

Stoewsand, G.S. 1995. Bioactive organosulfur phytochemicals in Brassica oleracea vegetables-A review. Food Chem. Toxicol. 33:537-543.

Tolra, R.P., C. Poschenrieder, R. Alonso, D. Barcelo, and J. Barcelo. 2001. Influence of zinc hyperaccumulation on glucosinolates in Thlaspicaerulescens. New Phytologist 151:621-626.

Verhoeven, D.T.H., H. Verhagen, R.A. Goldbohm, P.A. van denBrandt, and G. van Poppel. 1997. A review of mechanisms underlying anticarcinogenicity by Brassica vegetables. Chem.-Biol. Interactions 103:79-129.

Wittstock, U., and B.A. Halkier. 2002. Glucosinolate research in the Arabidopsis era. Trends in Plant Sci. 7:263-270.

Zhao, F.J., E.J. Evans, P.E. Bilsborrow, and J.K. Syers. 1994. Influence of sulphur and nitrogen on seed yield and quality of low glucosinolate oilseed rape (Brassica napus L.). J. Sci. Food. Agr. 63:29-37. 